\title{
TRENDS IN THE DEVELOPMENT OF AGRICULTURE IN CONDITIONS OF TAX REFORM IN GEORGIA
}

\author{
Vazha Verulidze ${ }^{1}$, PhD in Economics, Professor; Inguna Leibus ${ }^{2}$, Dr.oec., Professor \\ ${ }^{1}$ Batumi Shota Rustaveli State University; ${ }^{2}$ Latvia University of Life Sciences and Technologies
}

\begin{abstract}
At the current stage of development of the Georgian economy and in conditions of existing resources, only the agriculture sector can contribute to the reduction of high levels of poverty and unemployment in the country. Improper assessment of the role and importance of the sector, lack of programmes based on scientific research, inconsistent reforms led to the low competitiveness of Georgian agricultural production and the prevalence of imported products on the internal market. The aim of this paper is to assess the impact of tax reform on the development of the agriculture sector in Georgia, and to compare it with Latvia, as it has been implemented in both countries based on Estonian experience. It is substantiated by means of theoretical and empirical methods applied in the article, that the land reform, implemented in Georgia before the profit tax reform, as well as financing of certain projects in the sector, was carried out without proper analysis and assessment of expected risks. The research concludes that for the development of agriculture sector of Georgia, it is especially important, at the first stage, to elaborate and implement mechanisms of protection of internal market, develop the existing infrastructure, promote cooperative enterprises, extend tax benefits to all spheres of activities of agricultural cooperatives, commence the process of structural diversification and modernization of the sector, and overcome the obstacles existing on external markets.
\end{abstract}

Key words: development of agriculture, profit tax, corporate income tax, tax reform, Georgia. JEL code: Q14,Q18

\section{Introduction}

The paper examines the situation in the agriculture sector of Georgia for the last 6 years and the tendencies of development in the conditions of tax reform. The importance and relevance of the study lie in the determination of causes behind the unsuccessful implementation of Estonian experience of tax reform in the agriculture sector of Georgia and what we should expect in the conditions of Estonian experience of tax reform. The article presents the following research hypothesis - Without solving the situation existing in the agriculture, the tax reform will not be successful. The aim of this paper is to assess the impact of tax reform on the development of the agriculture sector in Georgia and to compare it with Latvia, as it has been implemented in both countries based on Estonian experience. The tasks of the research are: to study and analyse the existing situation in the agricultural sector of Georgia and elaborate the respective recommendations. The research object is state of agriculture in Georgia and tax policy in agriculture in Georgia.

The methodological basis of the research is the dialectical method of cognition that has enabled us to study the economic events and their interaction. The research methods like scientific abstraction, comparison of information, generalization, analysis and synthesis were also used. The empirical basis of the research is the official information of the National Statistics Office of Georgia, the normative acts of the Government of Georgia, the Georgian Tax Code and scientific publications.

Tax benefits in Georgia do not cover such fields of economic activities of agricultural cooperative as processing and realization of agricultural products; compared to 2015, the number of cooperatives decreased by 965 units (Legal status, 2020); the food self-sufficiency rate is low; import of food products in recent years almost did not decrease (Food Security, 2019); foreign direct investments in the sector are low (Foreign Direct Investments, 2020).

During the last three decades, despite the resources existing in the agriculture sector, elaboration of strategic plan of development, implemented tax reform, association agreement signed between Georgia and EU on 27 June 2014, and introduction of liberal trade regime with various countries, we 
got the situation when agriculture sector does not have a developed infrastructure, modern technologies are not implemented, qualification of farmers is low, cooperative enterprises are not developed, and competitive production is not produced. Protection of own internal market is of urgent necessity, in order to allow the sector to be prepared for functioning in a regime of competition. Many countries stick to this approach, including the countries in the European Union. Higher levels of support for EU agricultural producers are accompanied by higher levels of customs protection of the EU market (Pawlak K., 2018). It is also very important for Georgia to support the development of agricultural cooperatives. Agricultural cooperative provides comprehensive services for members, brings benefits to members and distributes proceeds to members. (Zhu Q., Wachenheimb C. J., Ma Z., Zhu C. 2018).

\section{Research results and discussion}

The challenges, which were faced by the agriculture sector of Georgia for years, their scope and efforts to overcome them point out the long-time inefficient economic policy adopted in this sphere. Therefore, it is an urgent necessity to speed up the process of structural diversification and modernization of the sector, which would ensure significant growth rates in the agriculture of Georgia and secure achievement of strong positions on the international market.

At this stage, the agriculture sector has a critical importance for Georgia to eliminate poverty, reduce unemployment and ensure the substantial improvement of living standards in the country. The issues of food security and food safety depend on the realization of the full potential of agriculture. The process of development in the agriculture is hindered by existence of weak and poorly developed infrastructure, lack of storage and refrigerator facilities, shortage of modern technologies and proper qualifications, chaotic situation in terms of irrigation and drainage systems and many more: therefore, the work efficiency and land productivity is extremely low. This negatively affects the competitiveness of the sector.

Since 2012, agriculture was declared one of the priorities of economic development in Georgia and the implementation of measures and projects started, aimed at facilitating the development of the sector (Our Village, 2015). Important steps were taken to revive practically destroyed the agricultural sector, including:

- The amount of GEL 636.671.877 (EUR 286.789.133) and USD 156.658.755 (EUR 117.846.900) was issued within the scope of the Preferential Agro Credit project;

- Various crops with the value of GEL 186.676.471 (EUR 79.436.796) were insured under the agriculture insurance programme;

- State co-financing for processing enterprises was USD 6.362.670 (EUR 4.873.534);

- Within the scope of the project for facilitating spring works of land-poor farmers, the agricultural lands with an area of 220.466 ha were cultivated;

- Under the "Plant Future" project, intensive type gardens were planted on the area of $89.63 \mathrm{ha}$;

- Until 20 September 2015, a status of the agricultural cooperative was granted to 1.162 cooperatives;

- Nationwide, 29 rehabilitation projects of ameliorative infrastructure are underway with the value of GEL 52.000.000 (USD 28.888.888) (EUR 22.127.659).

According to article 10 - "Agriculture and Development of Villages" of the Association agreement between Georgia and European Union signed on 27 June 2014, Georgia should ensure the development of villages and agriculture in accordance with the EU policy and best practice, and 
should align its legislation with the European one. In this process, it is very important that the mechanisms of tax regulation for the agriculture sector would be compatible with European policy. Currently, the applicable tax legislation in the country exempts from the land tax (Property tax Act, 2018) land plots up to 5 ha (as of 1 March 2004) in the ownership of natural persons, and this fact, in the given case, makes obstacles for unifying small parcels into agricultural cooperatives, because the land of such cooperatives would be taxed. In particular exempt from the property tax, only property owned by an agricultural cooperative, used in agricultural activity and movable property leased to it for the same activity (except land).

According to the Tax Code of Georgia taxable income earned from the primary supply of agricultural products produced in Georgia by a natural person engaged in agricultural production until 1 January 2023 if the gross income earned by the natural person from such supply during the calendar year does not exceed GEL 200000 (EUR 62.305) is exempted from the income tax (Income tax Act, 2019). This provision too curbs any incentives in natural persons to combine their land plots in cooperatives, because a supply of agricultural production from natural persons is exempted from the income tax, while in the case of processing the agricultural production and its further supply to the market, neither a natural person nor a cooperative enjoys any tax benefits. Profit earned by an agricultural cooperative from a primary supply of agricultural products made in Georgia before their industrial processing (changing their commodity code) exempt from profit tax (Profit tax Act, 2017). It means that the tax legislation does not extend tax breaks to all spheres of agricultural activities of agricultural cooperatives, which include: manufacturing, processing, collecting, packaging, storing, transporting and/or selling agricultural products (Law of Georgia..., 2019).

In the economy of the country Since 1 January 2017, the reform in relation to the profit tax was implemented among them in the agriculture sector, for the purpose of attracting internal investments. The main purpose of the reform was to implement a scheme, according to which in the case if a profit would not be distributed in the form of dividends, and would be reinvested, it will not be taxed. This was intended to become a basis for the development and expansion of enterprises including cooperatives. Although, in the conditions of this reform, the transformation of small private farms into cooperatives was not facilitated, which is proved by the fact that as of 1 June 2019, the status of acting subject was only held by 197 cooperatives (Legal status, 2020), while in 2015 this figure was 1162 . Georgia is characterized mainly by farmers with small land parcels; in agriculture $640 \mathrm{~K}$ households and only $2.2 \mathrm{~K}$ legal persons (Rural Development Strategy, 2019): - therefore, it is necessary to establish cooperatives as entrepreneurial subjects for the development of this sector.

In parallel to the reforms conducted in the agriculture sector, some steps were taken to introduce a liberal trade regime with certain countries (Economic Overview, 2017-2020). The agreement signed with the EU on the Deep and Comprehensive Free Trade Area (DCFTA) was provisionally entered into force on 1 September 2014. Georgia has also signed free trade agreements with the CIS and Turkey (2008), Most Favored Nation Treatment (MFN) with the member states of the World Trade Organization (WTO) and the General System of Preferences (GSP) with the USA, Canada and Japan. In 2016, Georgia concluded negotiations with the European Free Trade Association (EFTA) on creating a free trade area. Free Trade Agreement between Georgia and China entered into force in 2018.

According to researchers of the 2000 tax reform in Estonia, the main goal of the tax reform was to stimulate investment growth (Prohorov A., 2017). So far, we cannot see substantial economic results of the tax reform in Georgia. Georgia currently consumes more imported agricultural 
products, than produces them. The self-sufficiency ratio in terms of such important products as vegetables, milk and dairy products is decreasing since 2013. The self-sufficiency ratio for wheat is very low, which has also decreased since 2016 and currently stands at $15 \%$ (Figure 1). The same goes for the self-sufficiency ratio for meat. In 2018, compared to 2013, the import of agricultural production was not decreased significantly (Food Security, 2019), and compared to 2017 it even increased (the import of food products usually fluctuates in the range of around 1 billion dollars annually).

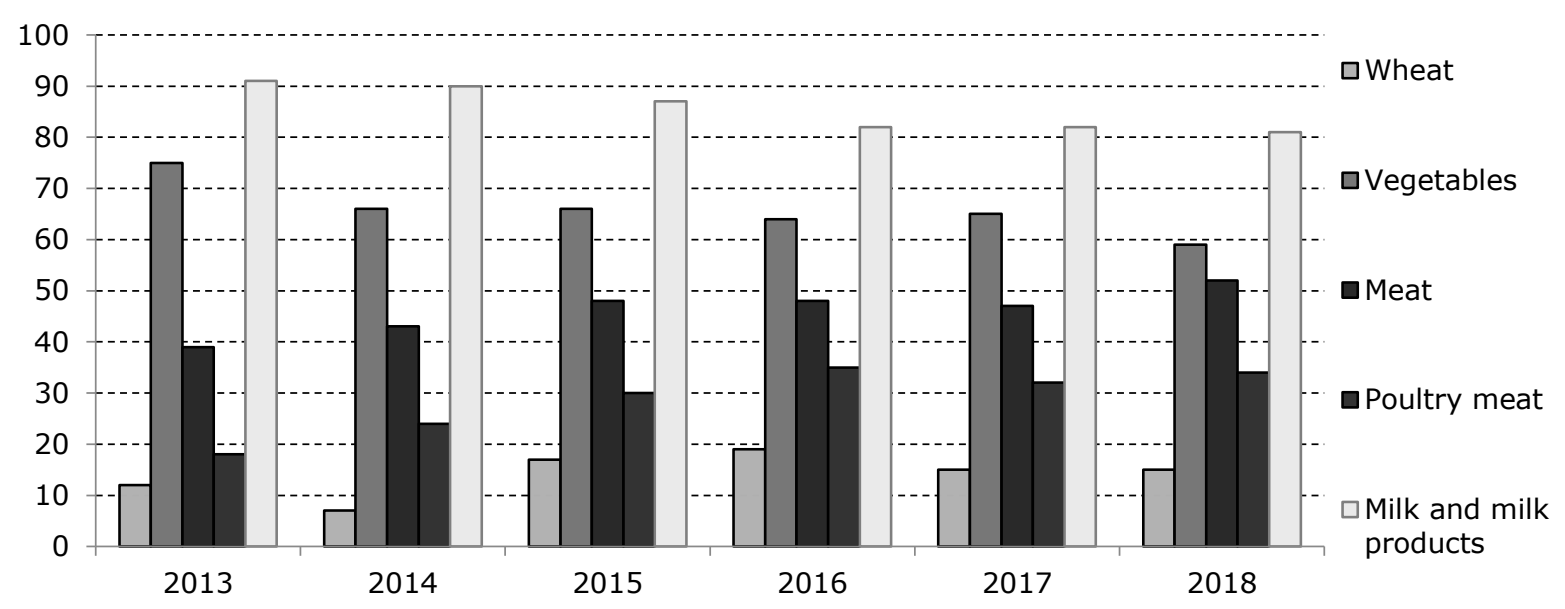

Source: National Statistics Office of Georgia

Fig. 1. Self-sufficiency ratio in Georgia in 2013-2018, \%

The situation existing in the agriculture sphere makes clear that at this stage the significant growth rates are not achieved, as well as technological modernization of leading segments, development of infrastructure, taking steps to clear the obstacles for Georgian products on the international markets, elaboration, and implementation of policy for replacing the cheap imported production by local production on the Georgian market, expansion of processing plants and their stimulation to work on local raw materials by means of law regulations, and breathing new life into agricultural cooperatives. Therefore, the food value chain development in all segments of agriculture proved to be weak (primary production, processing and storing infrastructure, marketing and realization), and it was not able to respond to the fierce competition, which was the result of trade liberalization. The share of agriculture in the GDP in 2018, compared to 2013 , decreased to $7.8 \%$ from $9.6 \%$ (General Agro Sector, 2020). In comparison, the share of agriculture in Latvia is smaller, but has increased slightly over the same period from $3.5 \%$ to $4.1 \%$ (Figure 2). The total share of agriculture, forestry and fishery in the GDP, at constant 2015 prices, in 2013 was GEL 2.679.3 M (EUR 1.206.8 M), in 2017 it was GEL 2.380.2 M (EUR 835.157.894) and in 2018 - GEL 2.708.7 M, (EUR 896.920.529) for 2018 This value increased only by USD 12.2 (EUR 10 M) million compared to 2013 (Gross Domestic Product, 2020). Foreign direct investments in the sector of agriculture and fishery in 2013 were USD 12.512.7 K (EUR 9.412.706 K), and in 2018 - minus USD 3.307.4 K (EUR 2.902.2 K), (Foreign Direct Investments, 2020) which means that foreign investments in the amount of more than three billion dollars, invested in the sector, were in some form withdrawn by investors. Investments in fixed assets of agriculture, forestry and fishery in 2013 were GEL $153.5 \mathrm{M}$ (EUR 69 M), in 2016 was GEL 179.9 M (EUR 67 M), in 2017 was GEL 128.3 M (EUR 45 M) and in 2018 was GEL 171.7 M (EUR 56 M) (Investments in fixed..., 2020), which means that reinvestment in 2018 compared to 2016 decreased. 
Thus, at this stage we can say that Georgia lacks a unified and consistent vision for the development of the agriculture sector, therefore, it is very important to understand to what extent the intervention of the state in the agriculture sector would be justified in the conditions of an open economy, so that to ensure the stable and irreversible process of development in the sector.

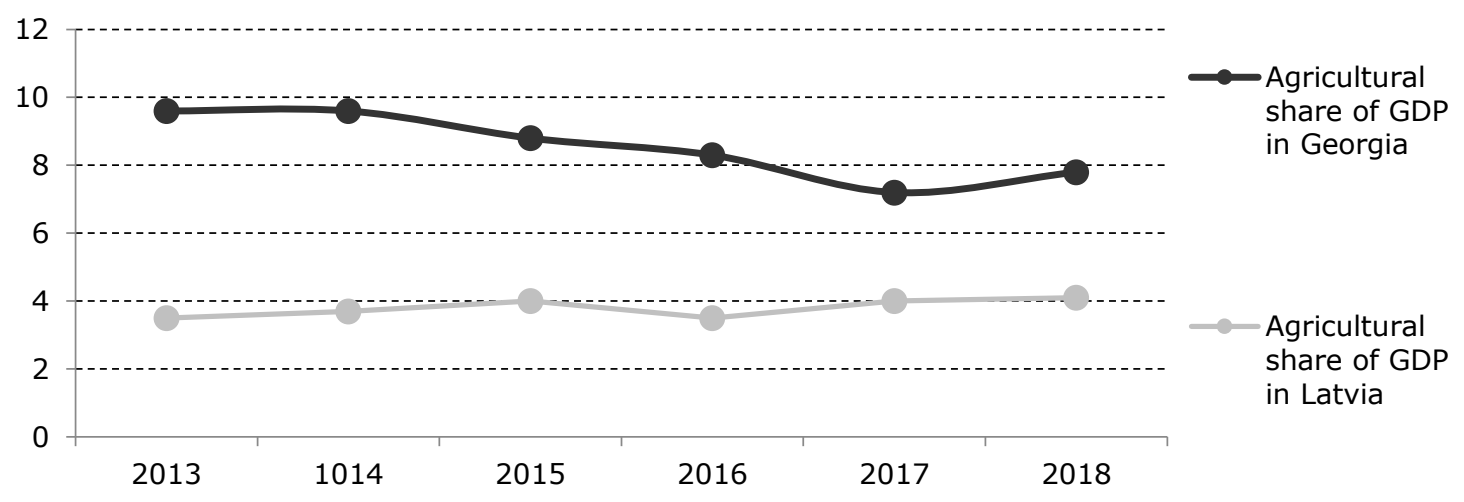

Source: National Statistics Office of Georgia, Central Statistical Bureau of Latvia

Fig. 2. Agricultural share of GDP in Georgia and Latvia, \%

Villages in Georgia are characterized by undesirable demographic tendencies; the rural population is declining on the year-to-year basis; persons under 36 make up around $6 \%$ of the total rural population (Rural Development Strategy, 2019). The motivation of young people to engage in agricultural activities will not only slow down the rate of migration but also will lay a foundation for the process of modernization in the agriculture sector, therefore Polish experience is very important for Georgia. One of the strengths of Polish agriculture is young age of agricultural producers compared to other European countries. In Poland, $14.7 \%$ of all farmer managers are under the age of 35 , while in the EU-27 on average $53.1 \%$ of farmers are people over 55. Undoubtedly, strengthening the support for young farmers is justified by the greater potential of innovation and entrepreneurship of this group of farmers and their openness to innovation and understanding the need to solve environmental problems. As many researchers have noted, supporting of this group of farmers allows to increase the dynamics of the agriculture modernization process and ensure longlasting, stable development (Brodzinski Z., 2019).

Facilitation of diversification of agriculture sector and development of non-agricultural activities in rural areas may create conditions for employment and a decent life for the rural population, it is also very important to develop multifunctional agriculture sector, which means promotion of nonagricultural industries in rural areas. In the European union, addition to the well-known and universal concept of sustainable development, on which all Community policies are based, including the (Common Agricultural Policy) CAP, the concept of multifunctional rural development is significant and capacious. The main assumption of this concept is the gradual departure from the domination of agriculture in the structure of the rural economy by development of additional, non-agricultural forms of economic activities and various functions of social services. Thus, on the one hand, this concept assumes the support for the agriculture modernization process, and on the other the acceleration of development of non-agricultural activities, which results in the general diversification of the rural economy (Adamowicz M., 2018).

In the agriculture sector of Georgia, $99.7 \%$ of undertakings are household enterprises, which also can be considered one of the main impeding factors for the development of the sector, because all of them have small land parcels and carrying out agricultural activities in these conditions is inefficient. The existing experience proves that the only solution in this situation is to promote 
agricultural cooperatives, which has also not been achieved in Georgia. Agricultural Cooperative provides comprehensive services for members, brings benefits to members and distributes proceeds to members. Benefits to members originate from three sources. First, production costs are reduced through increased market power for procurement of inputs and production efficiencies resulting from education and training. Second, sales revenues increase and market risk declines because of marketing efficiencies from economies of size and from cooperative storage, logistics, and marketing activities. Third, the cooperative increases access to and reduces the cost of credit for members (Zhu Q., Wachenheimb C. J., Ma Z., Zhu C. 2018).

It was proven in the study process that one of the main issues, which hinders a positive impact of Estonian experience on the development of farming enterprises in Georgia is an unprotected internal market, which is saturated with cheap imported products. According to 2018 data, the import accounted for $73 \%$ of the external trade (External Trade., 2019): therefore, the incentives for engaging in agricultural production are very low. The next problem, which also hinders the normal functioning of the agriculture sector, is the poor condition of irrigation and drainage systems, and other elements of infrastructure.

It should be noted that the reform was implemented in the part of profit tax, while other taxes, such as land tax and value-added tax, are not sufficiently adjusted to the purpose of development of the agriculture sector and extension of tax benefits on all spheres of agricultural activities of cooperatives. In these conditions, it is impossible to achieve a structural diversification and modernization of the agriculture sector.

As a result, the entrance of Georgian agricultural production on external markets is hampered by so-called Technical Trade Barriers (TBT), such as technical regulations, standards, procedures of certification. It is especially relevant for agricultural products. In Georgia, only few primary and finished food and agricultural products have an international certificate (Millns J., 2013).

If nothing changes, the country will remain in the situation of a very fragile economy based on tourism and import, with a weak base for the production of agricultural and food products, which eventually determines its instability against crises. Moving the policy and institutional reform agenda forward will require higher level of political commitment, increased investment support, systematic capacity development at the organizational and individual levels, functioning monitoring and evaluation system, and improved research-policy linkages (Ragasa C., Babu S., Ulimwengu J., 2014).

Latvia introduced the corporate income tax (CIT) reform in 2018 on the basis of the Estonian experience. The aim of the reform was to enhance business development by encouraging business owners to leave a larger share of their profits in the company; thus, contributing to the increase of investment. However, in this aspect as it shall be admitted the agricultural sector was in a better situation even before the tax reform compared with other sectors in Latvia on average. According to the data of the State Revenue Service of the Republic of Latvia, the share of equity in the capital structure of agricultural companies has slightly increased every year until the tax reform, for example, it has grown from $47 \%$ in 2015 to $49 \%$ in 2018 in contrast to the average indicator of Latvia, which had fallen from $44 \%$ to $40 \%$. The ratio of equity to long-term investment has also been more stable for the agricultural sector - $69 \%$ of long-term investment in agricultural companies were on average financed by the equity.

The better situation in the agricultural sector was mainly driven by the growing EU and national subsidies for agriculture, which still continue to grow with an increase of $16.4 \%$ between 2013 and 
2018. In fact, about $2 / 3$ of the income from agricultural production come directly from subsidies (56.5\% $-71.7 \%)$, which allowed farmers to increase their profits and become less dependent on the borrowed capital. In addition, it should be noted that agricultural companies in Latvia benefited significant tax reliefs also until 2018: the CIT was not calculated on the subsidies received, and the calculated CIT was reduced by EUR 14.23 per hectare of the utilised agricultural area (Leibus I., 2017).

In 2018, the CIT object was changed in Latvia due to the tax reform - the reinvested profit is no longer subject to the CIT. The new procedure for the CIT payment is very suitable for agricultural companies, especially in the crop sector. In agriculture, large investments are required for the purchase of agricultural land. Farmers mainly use the profits earned in previous years for this purpose. If, before the tax reform, farmers were liable to pay the CIT also on the part of profit used for the purchase of land, then the profit is no longer the tax object and is not taxable after the tax reform.

Consequently, it can be concluded that the development of agriculture in Latvia is mainly influenced by the EU and state aid payments. The impact of the tax reform on agriculture may not yet be assessed. However, it can be predicted that it will not be relevant, since significant tax reliefs and incentives have been applied in Latvia for a long time. Nevertheless, tax revenues from agriculture are increasing in recent years, this is mainly due to the rise in wages and salaries, and thus in the increase of the payroll tax and mandatory state social insurance contributions.

\section{Conclusion}

1) The agriculture sector of Georgia had the undeveloped infrastructure, unprotected internal market, obstacles and barriers to external markets, lack of up-to-date technology, and low investment attractiveness in the agriculture sector at the moment of tax reform implementation. In these conditions, the sector proved to be completely unprepared for liberal trade regimes, because it could not withstand the intense competition, and, as a result, the development process is significantly slowed down. This situation is especially negatively affecting the levels of poverty and unemployment in Georgia.

2) The tax reform implemented in the agriculture sector of Georgia, was not able to perform the stimulating role in the development of sector, because the situation existing in the sector before the reform, in particular, the undeveloped infrastructure and lack of mechanisms for protection of internal market (the issue, which was not resolved for the last three decades), hampered the normal functioning of agricultural activities. Without solving this problem in the first place, in our opinion, any attempts to facilitate the development of the agriculture sector by means of tax reform would be unsuccessful.

3) The tax legislation of Georgia does not facilitate a development of agriculture sector, including in the part of profit tax, and does not create conditions for promotion of activities of agricultural cooperatives and for overcoming the crisis existing in the sector, nor it promotes an implementation of modern technology, which would positively affect the process of overcoming the existing barriers to the external markets. Therefore, it is necessary to review the tax legislation in Georgia.

4) The development of agriculture in Georgia and Latvia is difficult to compare in terms of tax reform. The development of agriculture in Latvia is mainly influenced by the EU and state aid payments, 
as well as by significant tax reliefs that preceded the tax reform. The impact of the latest tax reform on agriculture may not yet be assessed.

\section{Bibliography}

1. Adamowicz, M. (2018). Normative Aspects of Rural Development Strategy and Policy in the European Union. Proceedings of the 2018 International Scientific Conference "Economic Science for Rural Development". Issue 47. Jelgava, LLU ESAF. p. 21.

2. Brodzinski, Z. (2019). Trends of the Process of Modernization of Farms Managed by Young Farmers. Proceedings of the 2019 International Scientific Conference "Economic Science for Rural Development". Issue 50. Jelgava, LLU ESAF. pp. 312-313.

3. Economic Overview: Rural Development Strategy Of Georgia For 2017-2020 (2017). Retrieved: http://business.org.ge/wp-content/uploads/2018/05/document-1.pdf Access:17.04.2019

4. External Trade: National Statistics Office of Georgia (2019). Retrieved: https://www.geostat.ge/en/modules/categories/35/external-trade Access: 12.02 .2020

5. Food Security: National Statistics Office of Georgia (2019). Exports and Imports Of Food, Retrieved: https://www.geostat.ge/en/modules/categories/297/food-security. Access:05.12.2019

6. Foreign Direct Investments: National Statistics Office of Georgia (2020). Foreign Direct Investments By Economic Sectors, Retrieved: https://www.geostat.ge/en/modules/categories/191/foreign-directinvestments. Access:18.01.2020.

7. General Agro Sector Statistics: National Statistics Office of Georgia (2020). General Agro Sector Statistics $2013-2018 . \quad$ Retrieved: https://www.geostat.ge/en/modules/categories/196/agriculture. Access: 30.01 .2020

8. Gross Domestic Product: National Statistics Office of Georgia. (2020). Gross Domestic Product at Constant Prices, Retrieved: https://www.geostat.ge/en/modules/categories/23/gross-domestic-product-gdp. Access: 20.01.2020.

9. Income Tax: Tax Exemption, Tax Code of Georgia (2019), article 82. Retrieved: https://matsne.gov.ge/en/document/view/1043717?publication=152. Access:15.11.2019.

10. Investments in Fixed Assets: National Statistics Office of Georgia (2020). Statistical survey of enterprises, Retrieved: Access:07.03.2020

11. Law of Georgia On Agricultural Cooperatives (2019). Areas of Activity of Agricultural Cooperatives, article 6. Retrieved: https://matsne.gov.ge/en/document/view/1972742?publication=3. Access:04.10.2019.

12. Legal status: National Statistics Office of Georgia (2020). Number of Registered and Active Entities By Organizational -Legal Form, Retrieved: https://www.geostat.ge/en/modules/categories/67/by-legal-status. Access:30.01.2020.

13. Leibus, I. (2017). Assessment of Agricultural Tax Burden in Latvia. Proceedings of the International scientific conference "Economic science for rural development", Issue. 46: New Dimensions in the Development of Society. Home Economics. Finance and Taxes, pp. 272-278

14. Millns, J. (2013). Agriculture and Rural Cooperation Examples from Armenia, Georgia and Moldova (FAO). Retrieved: http://www.fao.org/3/ar424e/ar424e.pdf Access: 07.02.2020.

15. Our Village (October 10, 2015) (2015). Report on the Activities of the Ministry of Rural Development $2013-$ 2015, Retrieved: http://www.alsc.ge/Ge/News/Paper/8 .Access: 05.09.2019.

16. Pawlak, K. (2018). Agricultural Support Policy as a Determinant of International Competitiveness: Evidence from the EU and US. Proceedings of the 2018 International Scientific Conference "Economic Science for Rural Development". Issue 47. Jelgava, LLU ESAF. p. 237

17. Profit Tax: Tax Exemption, Tax Code of Georgia (2017), article 99. Retrieved: https://matsne.gov.ge/en/document/view/1043717?publication=152. Access:15.11.2019.

18. Prohorov, A. (2017). Corporate Income Tax in Latvia And Estonia: Effects on Entrepreneurial Activity, Investment, The Unemployment Rate, Tax Revenues and the Economic Growth of the State. Jelgava. p. 224.

19. Property Tax: Tax Exemption, Tax Code of Georgia (2018), article 206., Retrieved: https://matsne.gov.ge/en/document/view/1043717?publication=152. Access: 12.10.2019.

20. Ragasa, C., Babu, S., Ulimwengu, J. (2014). International Reforms and Agricultural Policy Process: Lessons from Democratic Republic of Congo. Agricultural and Food Economics. Issue: 2, Article 4. Retrieved: https://agrifoodecon.springeropen.com/articles/10.1186/s40100-014-0004-3 Access:17.01.2020

21. Rural Development Strategy Of Georgia For 2021-2027 (ARDSG) (2019). P. 11 Retrieved: https://mepa.gov.ge/Ge/PublicInformation/16872 Access: 03.02.2020.

22.Zhu, Q., Wachenheimb, C.J., Ma, Z., Zhu, C. (2018). Supply Chain Re-engineering: a Case Study of the Tonghui Agricultural Cooperative in Inner Mongolia. International Food and Agribusiness Management Review. Issue 1 , Volume 21, pp. $157 . \quad$ Retrieved: https://www.wageningenacademic.com/doi/pdf/10.22434/IFAMR2016.0095 Access: 04.02.2020 